\title{
A NEW SPECIMEN OF AUSTRALERPETON COSGRIFFI BARBERENA, 1998 (STEREOSPONDYLI: RHINESUCHIDAE) FROM THE MIDDLE/UPPER PERMIAN RIO DO RASTO FORMATION, PARANÁ BASIN, BRAZIL
}

\author{
KARINE LOHMANN AZEVEDO \\ Programa de Pós-Graduação em Geociências, Universidade Federal do Rio Grande do Sul. Av. Bento Gonçalves, 9500, \\ 91501-970, Porto Alegre, RS, Brazil.karine.lohmann@gmail.com \\ CRISTINA SILVEIRA VEGA \\ Departamento de Geologia, Universidade Federal do Paraná, Curitiba, PR, Brazil. cvega@ufpr.br \\ MARINA BENTO SOARES \\ Departamento de Paleontologia e Estratigrafia, Instituto de Geociências, Universidade Federal do Rio Grande do Sul. Av. \\ Bento Gonçalves, 9500, 91.540-000, Porto Alegre, RS, Brazil.marina.soares@ufrgs.br
}

\begin{abstract}
Here we present a skull and a lower jaw of a temnospondyl specimen collected from the São Jerônimo da Serra Site, an exposure of the Morro Pelado Member of the Rio do Rasto Formation (Middle/Upper Permian, Paraná Basin), Paraná State of southern Brazil. The sedimentary environment in which the fossil was preserved is characterized by a massive reddish mudstone derived from the slow deposition of fine sediments from suspended load in a terminal splay or ephemeral lake setting. The comparative anatomical description of the new specimen allows its assignment to the rhinesuchid Australerpeton cosgriffi Barberena. The new specimen represents the most complete skull and lower jaw of this species found up to date. Its high degree of ossification associated with its large skull size (58 $\mathrm{cm}$ long) indicates that it was a mature adult. This work, besides confirming several anatomical characteristics of $A$. cosgriff, reveals previously unknown information about this species: a long cultriform process whose anterior edge surpasses the level of the posterior border of the choanas, being interposed between them; and a pair of longitudinal ridges lacking denticles that run parallel along the premaxillary surface without making contact with the choanae. These features were not reported before in the smaller known skulls of $A$. cosgriffi because they likely develop late in the ontogeny of this species. This new find provides evidence that this unique long-snouted rhinesuchid was a common and successful faunal component of the Middle-Late Permian fluvio/lacustrine ecosystems of southern Brazil, and reaffirms the Rio do Rasto Formation of Brazil as a rich source of information concerning the initial diversification of the Stereospondyli.
\end{abstract}

Key words: Australerpeton cosgriffi, Temnospondyli, Rhinesuchidae, Permian, Rio do Rasto Formation.

RESUMO - O trabalho apresenta um novo espécime de temnospôndilo que consiste em um crânio e uma hemimandíbula esquerda. O fóssil foi coletado no afloramento São Jerônimo da Serra, vinculado ao Membro Morro Pelado da Formação Rio do Rasto (Permiano Médio/ Superior, Bacia do Paraná), do Estado do Paraná, Brasil. O ambiente sedimentar no qual o fóssil foi preservado é caracterizado por pelitos maciços avermelhados gerados pela deposição de finos em suspensão, representando espraiamentos terminais e lagos efêmeros. A comparação detalhada do material permitiu a sua atribuição ao rinessuquídeo Australerpeton cosgriffi Barberena. O novo espécime representa os mais completos crânio e mandíbula já encontrados para esta espécie. O seu alto grau de ossificação associado ao grande tamanho craniano (58 $\mathrm{cm}$ de comprimento) indica tratar-se de um adulto pleno. Este trabalho, além de confirmar várias características anatômicas de $A$. cosgriffi, fornece informações inéditas para esta espécie, quais sejam: um longo processo cultriforme cuja extremidade anterior ultrapassa o nível da borda posterior das coanas, ficando interposto entre elas; um par de cristas longitudinais sem dentículos que correm paralelamente na superfície da pré-maxila, sem fazer contato com as coanas. Provavelmente estas características nunca haviam sido antes reportadas nos crânios de indivíduos menores de $A$. cosgriffi porque devem se desenvolver tardiamente na ontogenia desta espécie. O novo achado evidencia que este único rinessuquídeo longirostre era um componente faunístico comum e bem sucedido nos ecossistemas flúvio-lacustres do Permiano Médio/Superior do sul do Brasil, e reafirma a Formação Rio do Rasto como uma rica fonte de informação relativa à diversificação inicial dos Stereospondyli.

Palavras-chave: Australerpeton cosgriffi, Temnospondyli, Rhinesuchidae, Permiano, Formação Rio do Rasto. 


\section{INTRODUCTION}

The Rio do Rasto Formation (Gordon Jr., 1947) is part of the Middle/Upper Permian sequence from the Paraná Basin that crops out in southern Brazil across Paraná, Santa Catarina and Rio Grande do Sul states. This unit is subdivided into the 150-250-meter-thick Serrinha Member, that is formed dominantly by mudstones and fine-grained sandstones at the base, and the 250-300-meter-thick Morro Pelado Member, composed mainly of fine to medium-grained sandstones (Holz et al., 2010).

According to Langer et al. (2008), the fossiliferous outcrops of the Morro Pelado Member of the Rio do Rasto Formation are among the most important paleontological records of the continental Middle/Late Permian period in South America. Vertebrates, invertebrates, plants and ichnofossils have already been recorded from these strata (Barberena \& Daemon, 1974; Langer, 1998; Barberena \& Dias, 1998; Lee, 1997; Barberena, 1998; Richter \& Langer, 1998; Dias \& Barberena, 2001; Dias \& Kroeff, 2002; Leonardi et al., 2002; Malabarba et al., 2003; Cisneros et al., 2005; Dias \& Schultz, 2003; Eltink \& Langer, 2008, 2010, 2011; Cisneros et al., 2011; Ramos \& Vega, 2011; Souza \& Vega, 2011; Pauliv et al., 2012; Silva et al. 2012; Cisneros et al., 2012; Dentzien-Dias et al., 2012; Boos et al., 2013; Eltink \& Langer, 2014; Strapasson et al., 2015; Pauliv et al., 2014; Eltink et al., 2015; Boos et al., 2015; Boos, et al., 2016; Pacheco et al., 2017).

The study of temnospondyl amphibians from the Rio do Rasto Formation started in the 1970s with the publication of Platyops sp., a long-snouted Temnospondyli from Paraná State described by Barberena \& Daemon (1974). This specimen was later reassigned to Australerpeton cosgriffi Barberena, 1998, and further studies have added information about the postcranial skeleton of this taxon (Dias \& Richter, 2002; Dias \& Schultz, 2003; Ramos \& Vega, 2011; Eltink \& Langer, 2010, 2011, 2014). A. cosgriffi has previously been considered a member of Rhinesuchoidea (Barberena, 1998), Stereospondylomorpha Platyoposaurinae (Werneburg \& Schneider, 1996; Schoch \& Milner, 2000) and Rhinesuchidae (Dias \& Schultz, 2003). In the recent phylogenetic analysis performed by Eltink et al. (2015) A. cosgriffi nested within Rhinesuchidae, based mainly on the anatomy of the tympanic cavity.

Barberena \& Dias (1998) have also described a shortsnouted Temnospondyli from Paraná State that was identified as a "Rhinesuchus-like" form. From Rio Grande do Sul State, an incomplete lower jaw of the Platyoposaurinae Bageherpeton longignathus Dias \& Barberena, 2001 has been reported. An indeterminate Temnospondyli lower jaw (Malabarba et al., 2003) and a Melosaurinae incomplete skull (Dias-da-Silva, 2012) were also found in Rio Grande do Sul. Also from this region comes Konzhukovia sangabrielensis Pacheco et al., 2017, a member of the Konzhukovidae family, with close relationships to Russian forms, and the first temnospondyl from Santa Catarina State, the Stereospondylomorpha Parapytanga catarinensis Strapasson et al., 2015, was recently described. Most of these temnospondyl records from the Rio do Rasto Formation, as well as global ones, consist of cranial and mandibular remains.

Regarding Australerpeton cosgriffi, the first recovered remains were collected in the 1970 s from sites that crop out along the EFCP ("Estrada de Ferro Central do Paraná") railroad (Barberena \& Daemon, 1974; Barberena, 1998; Dias \& Schultz, 2003) in a geographic region known as Serra do Cadeado, located in the northeast of Paraná State. In the 2010s, new outcrops from the Serra do Cadeado were explored revealing more material of $A$. cosgriffi (Ramos \& Vega, 2011; Eltink \& Langer, 2014). São Jerônimo da Serra Site is where the new fossil material presented here was collected.

The present work describes a new skull and lower jaw of the Temnospondyli Australerpeton cosgriffi and presents a revised diagnosis with two new characters for the taxon.

Institutional abbreviations. UFPR PV, Universidade Federal do Paraná, Vertebrate Paleontology Collection, Curitiba, Paraná State, Brazil; UFRGS-PV-P, Universidade Federal do Rio Grande do Sul, Vertebrate Paleontology, Permian Collection, Porto Alegre, Rio Grande do Sul State, Brazil.

\section{GEOGRAPHICAL, GEOLOGICAL AND PALEONTOLOGICAL SETTINGS}

The materials reported here, a skull (UFPR 0199 PV) and a lower jaw (UFPR 0198 PV), were recovered in an outcrop named "São Jerônimo da Serra Site" located in the northeast of Paraná State at $277 \mathrm{~km}$ on the PR-090 road, between Sapopema and São Jerônimo da Serra municipalities (UTM $22 \mathrm{~K} 0538201 / 7368276$ ), in a geographic area known as Serra do Cadeado (Figure 1). This 180-meter-long outcrop is situated at an altitude of $1056 \mathrm{~m}$ and reveals a vertical exposure of approximately $25 \mathrm{~m}$.

The São Jerônimo da Serra Site exposes a sedimentary sequence identified as the Morro Pelado Member (Gordon, 1947), and displays a predominantly siltstone succession intercalated with layers of thin to medium sandstones. At its top, it is possible to observe a contact with the overlying eolian sandstones of the Piramboia Formation (Soares, 1975) (Figure 1).

Regarding its fossil content, plants, conchostracans, bivalves, paleonisciform fish scales, ostracods, bone elements (mainly from temnospondyls) and vertebrate ichnofossils have been recovered from this locality (Ramos \& Vega, 2011; Souza, 2011; Silva et al., 2012). Mandibular fragments (UFPR 0097 PV, UFPR 0100 PV and UFPR 0099 PV) collected at this site were tentatively identified as Australerpeton cosgriffi by Ramos \& Vega (2011). Although they are not well preserved, the typical dermal ornamentation of temnospondyl skull bones can be seen.

The vertebrate fossils usually occur in levels that are rich in iron oxide (hematite) and, in fact, are diagenetically altered and covered by a thick layer of this oxide, displaying a black color.

The fossil specimens here described were found at nearly 8 meters up from the base of the exposure, in a layer interpreted 
A

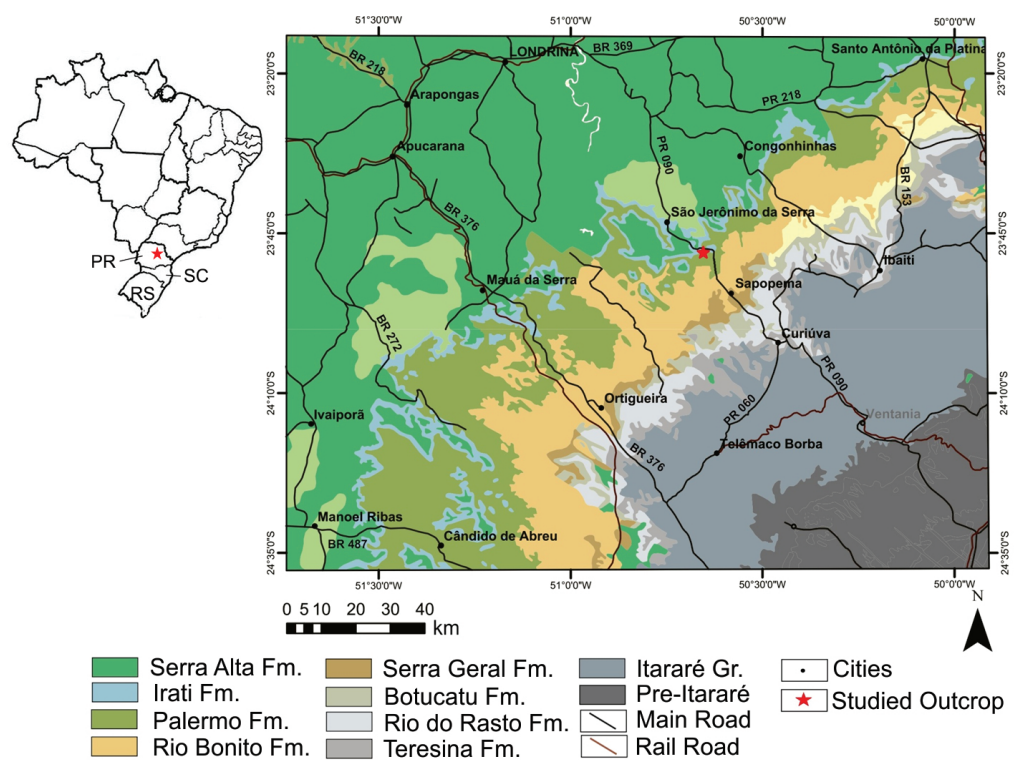

B

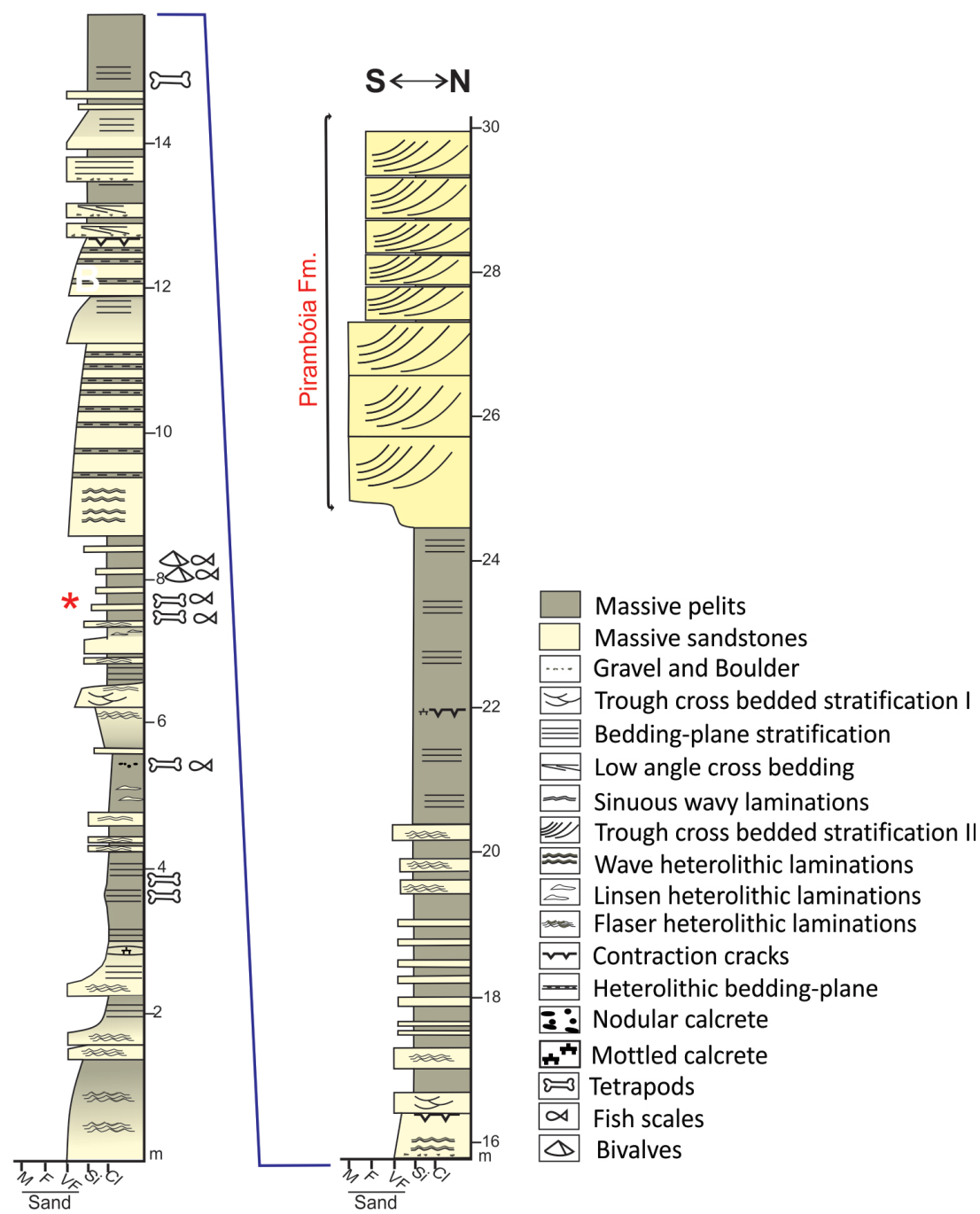

Figure 1. A, location map of the São Jerônimo da Serra Site (indicated by the star), Rio do Rasto Formation, in Paraná State (modified from Brasil, 2004). B, lithological profile of the São Jerônimo da Serra site showing the fossiliferous levels (modified from Schemiko, 2013). The star indicates the stratum where UFPR 0198 PV and UFPR 199 PV were found. Abbreviations: RS, Rio Grande do Sul State; SC, Santa Catarina State; PR, Paraná State. 
by Schemiko (2013) as a massive reddish mudstone derived from the slow deposition of fine sediments from suspension.

\section{MATERIAL AND METHODS}

The described materials, UFPR 0199 PV (skull) and UFPR 0198 PV (lower jaw), were found very close to each other at the same point and stratigraphic level, so it is safe to assign then to the same individual. They are housed in the fossil collection of the Laboratorio de Paleontologia (LabPaleo) of the Setor de Ciências da Terra of the Universidade Federal do Paraná (UFPR), in Curitiba, State of Paraná, Brazil.

As with all other fossil bones previously collected from the Jerônimo da Serra Site, UFPR 0199 PV and UFPR 0198 $\mathrm{PV}$ are adhered to the rock and coated by a dense layer of iron oxide. This coating is hard to remove and also makes difficult the observation of sutures and some important anatomical characteristics. Therefore, mechanical preparation with a pneumatic hammer and Paraloid B-72 resin was needed. Some attempts of chemical preparation with hydrogen peroxide were made, but this methodology was not efficient due to the large size of the specimen. Also, a CT Scan of the jaw was done but the results were not clear enough. In order to prepare both sides of the jaw UFPR 0198 PV, Carbowax resin was used. Due to the fragility of the skull UFPR 0199 PV, only its ventral view was prepared.

The description and comparisons were carried out based on literature and on specimens from the collections of the Laboratório de Paleontologia de Vertebrados of Universidade Federal do Rio Grande do Sul, Porto Alegre, Rio Grande do Sul, Brazil (UFRGS-PV-0224-P, UFRGS-PV-0225-P, UFRGS-PV-0227-P, UFRGS-PV-0228-P, UFRGS-PV0229-P, UFGRS-PV-0230-P, UFRGS-PV-0317-P) and the Universidade Federal do Paraná (UFPR 0097 PV, UFPR 0099 PV, UFPR100 PV).

The material here studied is attributed to Australerpeton cosgriffi, described by Barberena et al. (1998) and recently revised by Eltink et al. (2015) with more details added. A. cosgriffi is a Rhinesuchidae already recorded in the Rio do Rasto Formation from Paraná State; however, a few, but informative features found on the specimens studied here are listed below.

\section{SYSTEMATIC PALEONTOLOGY}

\author{
TETRAPODA Goodrich, 1930 \\ TEMNOSPONDYLI Zittel, 1887-90 \\ STEREOSPONDYLOMORPHA Yates \& Warren, 2000 \\ STEREOSPONDYLI Fraas, 1889 \\ RHINESUCHIDAE Watson, 1919 \\ AUSTRALERPETINAE Eltink et al., 2015
}

Australerpeton cosgriffi Barberena, 1998

(Figures 2-4)

\footnotetext{
Holotype. UFRGS-PV-0227-P.

Paratypes. UFRGS-PV-0228-P; UFRGS-PV-0229-P; UFRGS-PV-0230-P.
}

Referred specimens. UFRGS-PV-0224-P; UFRGS-PV0225-P; UFRGS-PV-0240-P; UFRGS-PV-0243-P; UFRGSPV-0319-P; UFRGS-PV-0320-P; LPRP/USP-0011; UFRGSPV-0228-P; UFPR 0097 PV; UFPR 0100 PV; UFPR 0099 PV. New referred specimens. UFPR 0199 PV, skull and UFPR 0198 PV, lower jaw.

Geological and geographical procedence. Morro Pelado Member, Rio do Rasto Formation, São Jerônimo da Serra Municipality, at the outcrop named "São Jerônimo da Serra Site” (UTM 22K 0538201 / 7368276), Paraná State, Brazil. Age. Middle/Late Permian.

Emended diagnosis. In addition to the diagnostic characters postulated by Barberena (1998), Dias \& Schultz (2003), Eltink \& Langer (2014) and Eltink et al. (2015), we propose the following characters $(*=$ autapomorphies) to diagnose adult individuals of Australerpeton cosgriffi: a long cultriform process whose anterior edge surpasses the level of the posterior border of the choanas, being interposed between them (shared with Mastodonsaurus giganteus, Konzhukovia vetusta and $K$. sangabrielensis); a pair of longitudinal ridges devoid of denticles that run parallel along the premaxilla surface without making contact with the choanae*.

\section{DESCRIPTION AND COMPARISONS}

\section{General skull aspect}

As explained above, only the ventral view of the skull UFPR 0199 PV was exposed, not being possible to prepare the opposite side owing to the fragility of the material. The skull exhibits a triangular shape with an elongated snout that ends with a slightly expanded premaxillary tip (Figure 2). It is $58 \mathrm{~cm}$ long and, in general, the skull is well preserved, being broken only in the left posterolateral portion. This skull morphology, which is usually related to a piscivorous diet (Dias \& Schultz, 2003), is typical of Australerpeton cosgriffi and it is also observed in stereospondylomorphs like Platyoposaurus stuckenbergi according to Gubin (1991). The shape of the rostrum is compatible with several A. cosgriffi specimens (e.g. UFRGS-PV-0227-P; UFRGSPV-0225-P; UFRGS-PV-0228-P), but the size of the skull UFPR 0199 PV surpasses the previously largest-known specimen, UFRGS-PV-0228-P, a rostrum which belonged to an animal with an estimated skull size of $c a .50 \mathrm{~cm}$. It is also important to emphasize that while UFRGS-PV-0228-P is an isolated rostrum, UFPR $0199 \mathrm{PV}$ is a complete skull, never before recorded for $A$. cosgriffi. A large number of teeth are preserved; they are rounded in cross-section, having the typical infolding internal labyrinthodont pattern. The external surfaces are marked by longitudinal grooves. In general, the teeth of UFPR 0199 PV decrease in size posteriorly. The pair of elongated choanas can be easily seen, as well as the wide interpterygoid vacuities and the long parasphenoid cultriform process. On the posterior part of the parasphenoid cultriform process there are two unidentified fragments of bones. The posterior portion of the skull (on the left side) is broken, and thus, part of the pterygoid, the subtemporal fenestra, the quadrate and the quadratojugal are missing. 

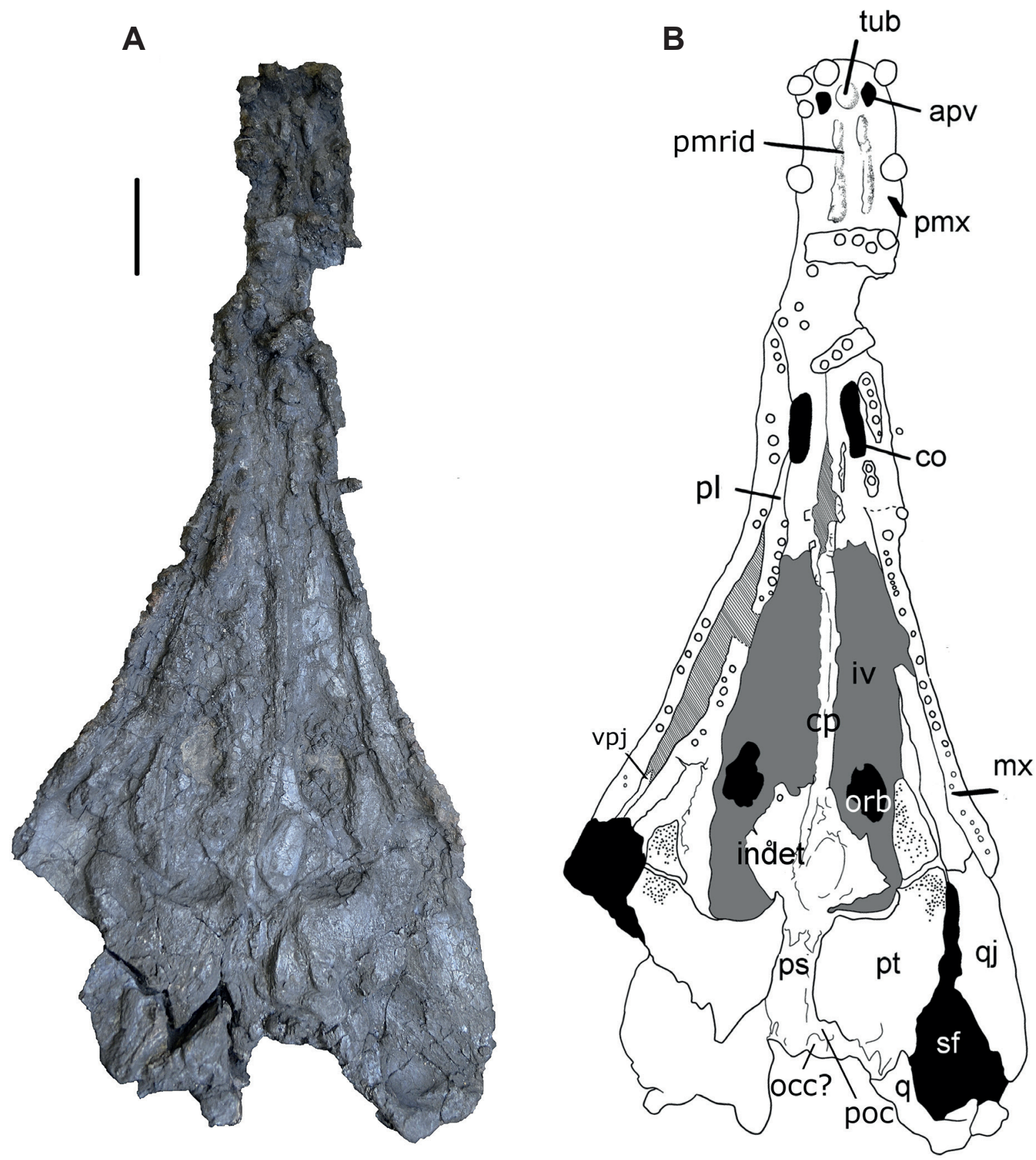

Figure 2. A, photo of the skull UFPR 0199 PV in ventral view. B, reconstruction. Black areas represent orbital openings and subtemporal fenestra. Grey area represents the interpterygoid vacuities. Shaded lined areas represent recessed areas of bone, and dots represent denticles on the palate. Abbreviations: apv, anterior palatal vacuity; co, choana; $\mathbf{c p}$, cultriform process; pmrid, premaxillary ridges; iv, interpterygoid vacuity; $\mathbf{m x}$, maxilla; ec, ectopterygoid; pl, palatine; pmx, premaxilla; ps, parasphenoid; pt, pterygoid; q, quadrate; qj, quadratojugal; sf, subtemporal fenestra; tub, medial tubercle of the premaxilla; v, vomer; orb, orbit; vpj, ventral process of the jugal; poc, 'pockets' for the insertion of the occipital musculature; occ, occipital condyle. Scale bars $=50 \mathrm{~mm}$.

The orbits are placed in the medial part of the skull through the interpterygoid vacuities. Ignoring the thick layer of iron oxide covering the bones, the osseous tissue is usually very thin, being nearly $4 \mathrm{~mm}$ thick.

Premaxilla. This bone is longer than wide, $13 \mathrm{~cm}$ in length, and more than twice the length of the external naris, defining a long-snouted condition like in Australerpeton cosgriffi. There are five tusks on the premaxilla, bent slightly backwards. On the anteriormost part of the bone, there is a small central tubercle similar to the one found in rhinesuchids like Rhineceps nyasaensis (Haughton, 1927) according to Watson (1962). Behind the tubercle there is a pair of fossae, the anterior palatal vacuities, which set the jaw teeth (Figure 2). These fossae are clearly separated, opposite to the condition seen in Platyoposaurus stuckenbergi, in which they appear as just one bilobed structure (Gubin, 1991) or in Eolydekkerina magna and Lapillopsis nana (Shishkin et al., 1996; Yates, 1999), in which the palatal vacuity is a single 

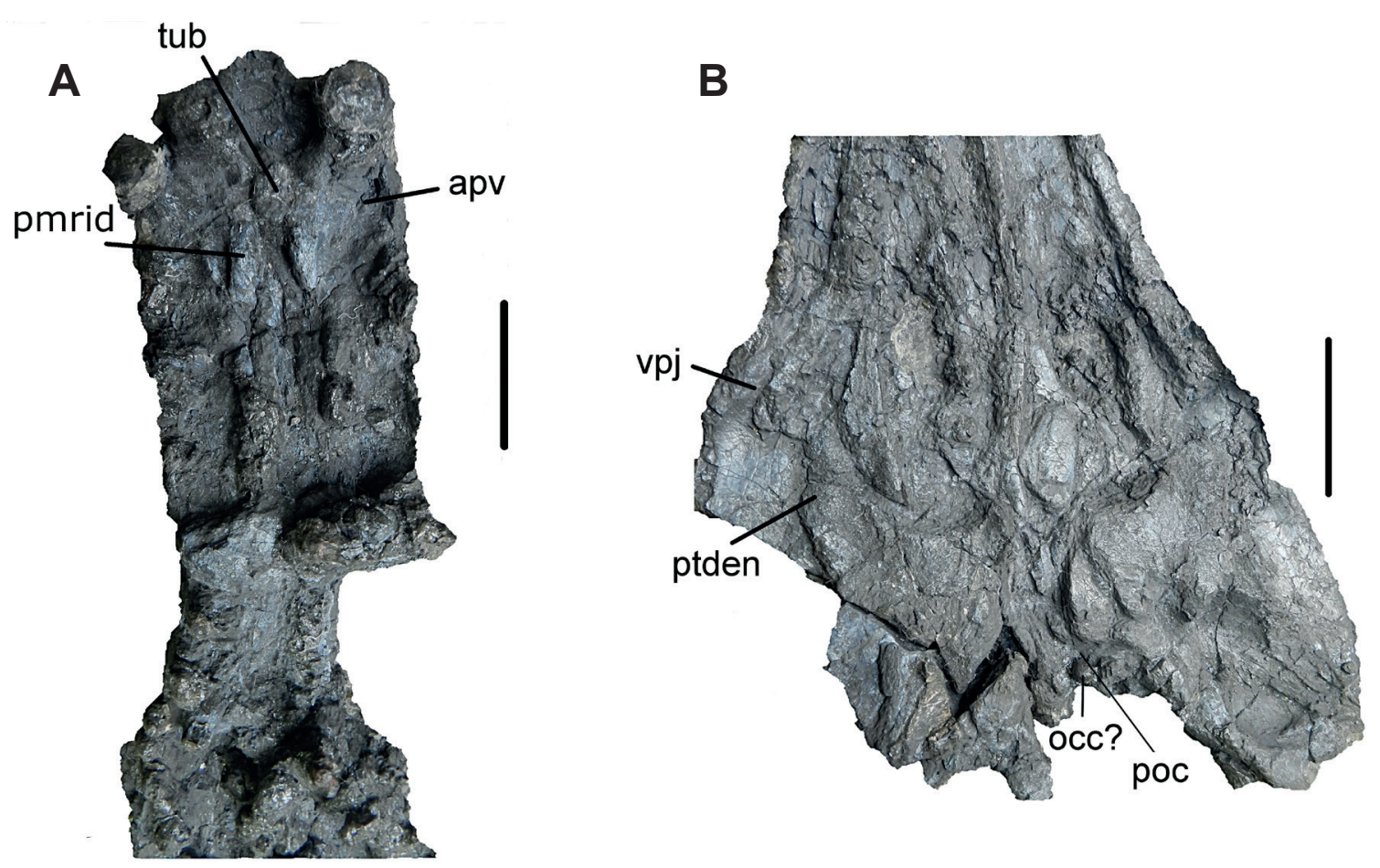

Figure 3. Photo of the skull UFPR 0199 PV in ventral view. A, anterior part; B, posterior part. Abbreviations: apv, anterior palatal vacuity; pmrid, premaxillary ridges; ptden, denticle os pterigoyd; tub, medial tubercle of the premaxilla; vpj, ventral process of the jugal; poc, 'pockets' for the insertion of the occipital musculature; occ,occipital condyle. Scale bars: $A=30 \mathrm{~mm} ; B=50 \mathrm{~mm}$.

A

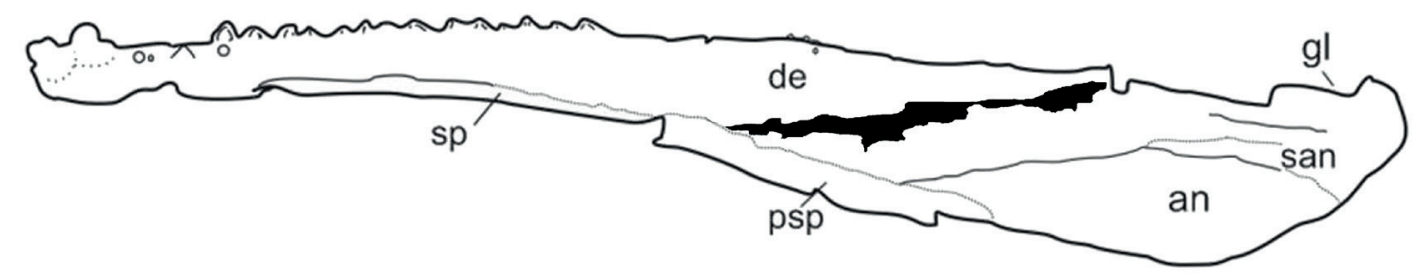

B

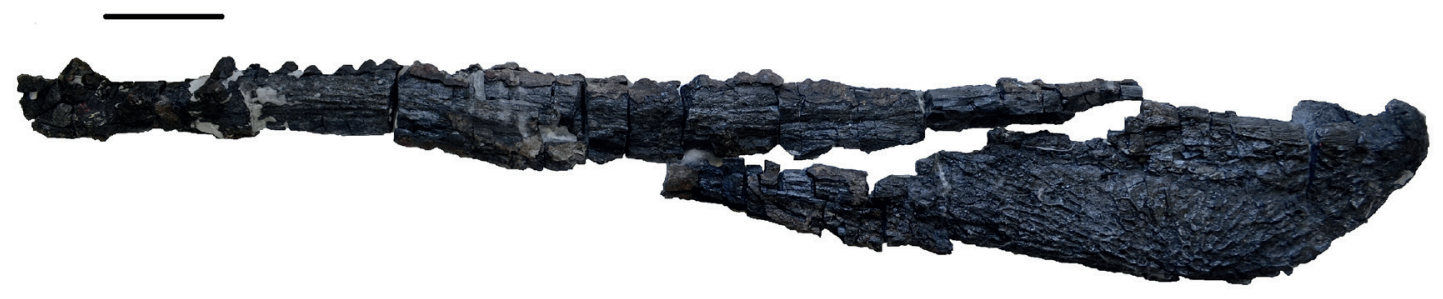

C

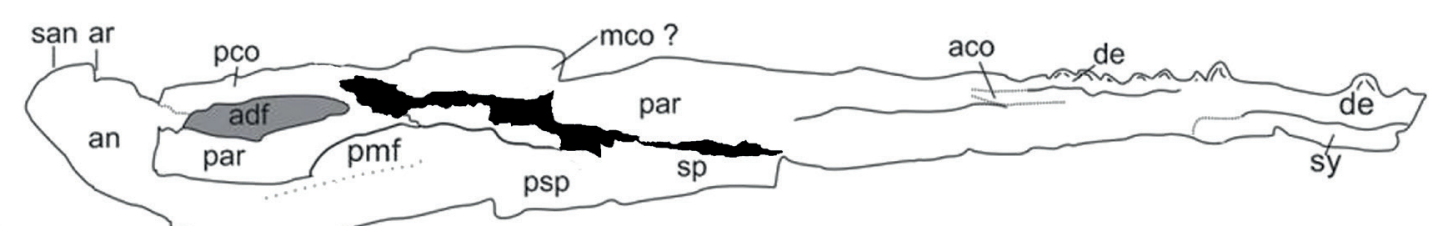

D

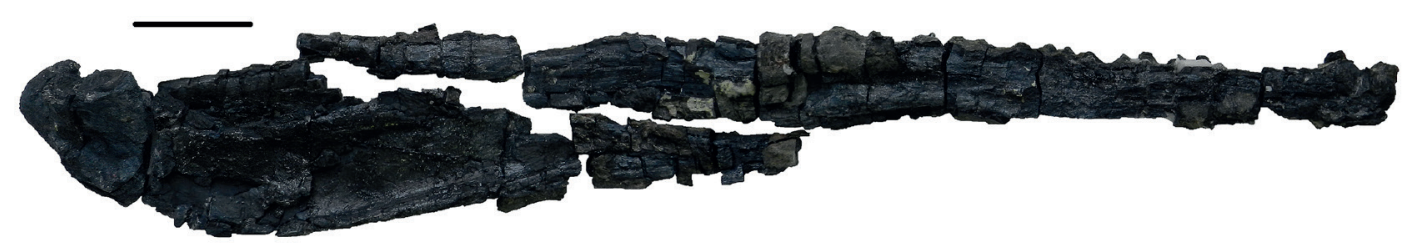

Figure 4. UFPR 0198 PV, left mandible. A, drawing of labial view; B, photo in labial view; C, drawing of lingual view; D, photo of in lingual view. Abbreviations: an, angular; de, dentary; pco, posterior coronoid; mco, middle coronoid; aco, anterior coronoid; psp, postsplenial; san, surangular; ar, articular; sp, splenial; pmf, posterior Meckelian fenestra; sy, symphysis; par, prearticular; adf, adductor fossa; pga, post-glenoid area. Black areas represent recessed bones. Scale bars $=50 \mathrm{~mm}$. 
structure without divisions. As in UFPR 0199 PV, Eltink et al. (2015) described these structures in A. cosgriffi, in which the central tubercle is well developed and the anterior palatal vacuities are placed posterior, but close to it. Posterior to the tubercle, and medial to the anterior palatal vacuities, UFPR 0199 PV exhibits a pair of prominent longitudinal ridges devoid of denticles or tusks that run parallel along the premaxilla surface (Figure 2C), resembling what was described in Archegosaurus decheni by Witzmann (2006). However, the ridges of Archegosaurus are placed in the vomer, instead in the premaxillae. Therefore, Witzmann (2006, p. 145; figs. 17, 18b) reported for Archegosaurus "an elevated strip of bone bearing teeth and denticles begins anteromedial to the choana and extends posteriorly parallel to the medial choanal margin at least in large and mediumsized skulls. On its widest part, the elevation bears a large tusk with appropriate, anteromedially located replacement pit. Apart from these teeth, the elevation is covered densely by denticles". In this taxon, the choanae anterior margins are placed in the vomer but very close to the premaxillae posterior limit, while in the Brazilian form the choanae are placed more posteriorly, in the middle portion of the vomer surface, far from the premaxillae posterior border. Although it is not possible to see how far the ridges extend along the palate in UFPR 0199 PV, they do not run parallel to the whole medial choanal borders as in Archegosaurus. Our considerations are reinforced by the holotype of Australerpeton (UFRGS-PV0227-P), in which the vomer was preserved and no sign of any ridges is observable on its surface (Barberena 1998; Eltink et al., 2015). Such premaxillary ridges had never been described for $A$. cosgriffi, probably because UFPR $0199 \mathrm{PV}$ is the most complete specimen found to date and the only one with good preservation of the whole rostrum. In addition to UFPR 0199 PV, only a single preserved rostrum (UFRGS-PV-0228-P) with preserved premaxillae is known, but although in this specimen it is possible to see the tubercle, it is not possible to observe if the ridges are also present because the anterior end of the rostrum is laterally compressed, and in consequence the palate is obliterated by the two teeth rows. We consider these premaxillary ridges as an autapomorphy of $A$. cosgriffi, since they are different from that of Archegosaurus decheni in their position, respectively premaxillae and vomer, and due to the absence of denticles or tusks in the former and their presence in the latter. Three tusks are placed anteriorly to the palatal vacuities and central tubercle, right at the tip of the snout, while another two large teeth are symmetrically positioned on each side, posterior to the anterior palatal vacuities and lateral to the premaxillary ridges. Besides these, there is no sign of any small premaxillary teeth. This organization differs from the reconstruction of $A$. cosgriffi presented by Barberena (1998), based on UFRGS-PV-0228-P, a rostrum, in which two or three premaxillary tusks are positioned on each side anterior to the palatal vacuities, two small teeth are placed lateral to the palatal vacuities and three more posterior larger teeth complete the series. This is the same condition described by Eltink et al. (2015) in A. cosgriff. The posterior enlargement of the premaxillary teeth, a character included in the diagnosis of $A$. cosgriffi by Eltink et al. (2015) and which makes it different from all other known rhinesuchids, is not well observed probably because the small premaxillary teeth are not preserved. This premaxillary tooth enlargement is also observed in some archegosaurids like Archegosaurus decheni (Witzmann, 2006; Eltink et al., 2015). There is a displaced fragment of the maxilla just over the contact area between the premaxilla, maxilla and vomer, precluding the visualization of the sutural relationships.

Maxilla. The maxilla surrounds the skull laterally, reaching the anterior edge of the subtemporal fenestrae, and bears teeth along its whole extension. At least 24 teeth can be observed on the right side and 16 on the left. This is a very low number in comparison to UFRGS-PV-0228-P, which bears 55 to 57 maxillary teeth (Barberena, 1998). Probably many teeth were detached from their alveoli and the iron oxide cover precludes their observation. Even tough, there is possible to observe that the teeth become smaller posteriorly as in Australerpeton cosgriffi (Eltink et al., 2015). The maxilla borders most of the anterolateral part of the choana, and then contacts the vomer anteromedially. As already mentioned, is not possible to observe its anterior contact with the premaxilla. The maxilla is delimited by the palatine on its posteromedial side as in Platyoposaurus stuckenbergi, Prionosuchus plummeri, Melosaurus spp. and A. cosgriffi (Gubin, 1991; Schoch \& Milner, 2000; Eltink et al., 2015). Posterior to the palatine, the medial border of the maxilla meets the ectopterygoid along a long suture. The contact with the quadratojugal is situated on the lateral border of the subtemporal fenestra. The maxilla participates in the anterolateral margin of the subtemporal fenestra as in other $A$. cosgriffi specimens. This character is shared with $A$. decheni (Witzmann, 2006; Eltink et al., 2015). As in A. cosgriffi (Barberena, 1998; Eltink et al., 2015), apparently there are no tusks in the maxilla, differing from platyoposaurines (like Platyoposaurus and Prionosuchus) and the cochleosaur Nigerpeton (Steyer et al., 2006). Nevertheless, we must consider that the premaxillarymaxillary region is distorted precisely in the place where the tusks may have been present. In consequence, we cannot confirm this character.

Vomer. The vomers take up great part of the rostral region. Each bone contacts anteriorly with the premaxilla along a suture, which cannot be seen. Anteromedially, it contacts the maxilla, and most posterolaterally, the palatine. The vomer borders the choana anteromedially and posteromedially, and makes up the anterior rim of the interpterygoid vacuity that is present in both Stereospondyli and higher non-Stereospondyli stereospondylomorphs (Gubin, 1991). Denticles and tusks are not seen on the surface of the vomer, differing from the holotype of A. cosgriffi (UFRGS-PV-227-P) (Barberena, 1998; Eltink et al., 2015). However, because of the superposition over the vomer of part of the cultriform process and what is probably the maxilla, it is not possible to assure with certainty that both the denticles and the vomerian tusks are absent or damaged.

Palatine. The palatine is better preserved on the left side of the skull in ventral view. It encompasses the anterolateral border 
of the interpterygoid vacuity. Laterally, it contacts the maxilla and forms part of the posterolateral border of the choana as in Australerpeton cosgriffi (Barberena, 1998; Eltink et al., 2015). The same condition described by Barberena (1998) and Eltink et al. (2015) for the positioning of the palatine in A. cosgriffi is here assumed, that is the palatine preventing contact between the vomer and the pterygoid. This state differs from that found in basal temnospondyls, in which the vomer contacts the palatine ramus of the pterygoid. Some Temnospondyli like Kosukovia vetusta, Eryops megacephalus and Australerpeton cosgriffi (Gubin, 1997; Pawley \& Warren 2006; Eltink et al., 2015) have palatine tusks. UFPR 199 $\mathrm{PV}$ also has a tusk (only one, on the right side of the skull) posterior to the choana, in the same position as the palatine tusk in the A. cosgriffi holotype (Barberena, 1998). However, Eltink et al. (2015) reported the presence of two tusks on the palatine of $A$. cosgriffi.

Ectopterygoid. The ectopterygoid is a narrow bone, located between the pterygoid (medially) and the maxilla (laterally). In UFPR 199 PV the ectopterygoid is overlapping the pterygoid, and although probable, it is not possible to confirm the contribution of the ectopterygoid to the margin of the subtemporal fenestra, as in Australerpeton cosgriffi (Eltink et al., 2015). Some denticles are seen on the preserved portion of the ectopterygoid in both sides of the skull.

Jugal. The ventral process of the jugal in UFPR 199 PV is visible only in the left side of the skull (Figure 3B) and its sutural relationships are not clear enough, but it can be seen that this process forms the anterior border of the subtemporal fenestra within the ectopterygoid. The same condition was considered by Eltink et al. (2015) as an autopomorphy of Australerpeton cosgriffi.

Pterygoid. Both pterygoids of UFPR 0199 PV are broken in the same area in their medial portion. It is hard to observe the palatine ramus as well as its anteriormost limit. However, we can infer that in UFPR 0199 PV, as in Australerpeton cosgriffi, the palatine ramus of pterygoid does not reach the vomer (Eltink et al., 2015). This is the typical condition of the advanced Stereospondyli (Milner, 1990; Gubin, 1997). Medially, the pterygoid body forms an extensive suture with the parasphenoid as seen in some rhinesuchids like A. cosgriffi (Eltink et al., 2015) and Laccosaurus watsoni (Haughton, 1925) and contacts the subtemporal fenestra. The posterolateral border of the interpterygoid vacuity is defined by the palatine ramus of the pterygoid. The quadrate ramus of the pterygoid reaches the posterior border of the skull and contacts the quadrate. There are denticles covering he ventral part of the pterygoid as seen by Eltink et al. (2015) in A. cosgriffi, as well as observed in Platyoposaurus stuckenbergi (Figure 3B). The pterygoid of UFPR 0199 PV lacks ornamentation as in A. cosgriffi and Rhineceps nyasaensis, differing from some stereospondyls like Lydekkerina huxleyi, Laccosaurus watsoni and Uranocentrodon senekalensis (Watson, 1962; Yates \& Warren, 2000; Schoch \& Milner, 2000; Eltink et al., 2015).

Parasphenoid. In UFPR 0199 PV the parasphenoid body is very developed. It contacts laterally with the pterygoid, and anteriorly it projects a thin and long cultriform process. This process is broken at its anteriormost part and has slid to the right over the vomer. The cultriform process is very long (approximately $25 \mathrm{~cm}$ ), surpassing the anterior border of the vacuities and reaching the level of the choanas on the vomer. There are differences between the lengths of this process among known specimens of $A$. cosgriffi. In UFRGS-PV-0227-P and UFRGS-PV-0229-P, the cultriform process extends anteriorly to the anterior margin of the interpterygoid vacuity, differing from the shorter cultriform process of UFRGS-PV-0224-P. Barberena (1998) described Australerpeton cosgriffi as having a process reaching 13.7 $\mathrm{cm}$ in length (in a skull of nearly $50 \mathrm{~cm}$ length) and almost reaching the level of the choanas. UFPR 0199 PV has the longest cultriform process among $A$. cosgriffi specimens. In this specimen the anterior edge of the cultriform process is inserted between the vomers, as in other described $A$. cosgriffi specimens as well as in other rhinesuchids (Schoch $\&$ Milner, 2000), but it surpasses the level of the posterior border of the choanas, being interposed between them. This condition is unprecedented for $A$. cosgriffi, and it is also observed in Mastodonsaurus giganteus, Konzhukovia vetusta and $K$. sangabrielensis (Pacheco et al., 2017). The parasphenoid borders the oval and elongated interpterygoid vacuities medially for its full extension. The interpterygoid vacuities in UFPR $0199 \mathrm{PV}$ are nearly $18 \mathrm{~cm}$ in length in around a $58 \mathrm{~cm}$ skull, almost the same proportion described by Barberena (1998) for $A$. cosgriffi. This author described interpterygoid vacuities $13.7 \mathrm{~cm}$ long in a skull of $50 \mathrm{~cm}$ in length (UFRGS-PV-0227-P). The interpterygoid vacuities of UFPR 0199 PV have a total width of $4 \mathrm{~cm}$, which corresponds to less than $90 \%$ of their length as in Konzhukovia gabrielensis (Pacheco et al., 2017). This pattern of longer than wide interpterygoid vacuities is also found in $A$. cosgriffi (Eltink et al., 2015). Denticles, frequently observed on Stereospondyli parasphenoids, including that of $A$. cosgriffi (Eltink et al., 2015), are not observed in UFPR 0199 PV, particularly the denticles reported by Eltink et al. (2015) on the posterior margin of the parasphenoid. Posteriorly, the semicircular 'pockets' for the insertion of muscles as in $A$. cosgriffi (Barberena, 1998) are partially present in the parasphenoid of UFPR 0199 PV.

Quadratojugal. It is a wide bone that laterally borders the subtemporal fenestra and posteriorly joins the quadrate. It contacts with the maxilla as observed in Australerpeton cosgriffi by Eltink et al. (2015).

Quadrate. The quadrate is a robust bone that borders the posterior area of the subtemporal fenestra. It is limited medially by the pterygoid and laterally by the quadratojugal. As in A. cosgriff, other rhinesuchids and also archegosaurids, the mandibular articulation is positioned posteriorly relative to the occipital condyles (Barberena, 1988; Eltink et al., 2015). The rugose surface texture of the quadrate mentioned by Eltink et al. (2015) for A. cosgriffi was not observed in UFPR 0199 PV.

Mandible. UFPR $0198 \mathrm{PV}$ is a completely preserved mandibular left ramus, although it is fragmented into 11 parts (Figure 4). It is $57 \mathrm{~cm}$ long. In the same way as UFPR 0199 PV, it is covered by a thick layer of iron oxide. Due to the presence of fractures and the oxide layer, some sutures 
were only able to be inferred and are dotted or not identified on the figures. In general, the anterior edge is lateromedially expanded and forms a spoon-shaped tip as in Australerpeton cosgriffi (Eltink \& Langer, 2014). The mandibular depth increases posteriorly. In labial view, the rough ornamentation on the posterior region can be easily observed, mainly on the angular where it has a polygonal sculpture as seen in $A$. cosgriffi and several temnospondyls like Mastodonsaurus giganteus and Gerrothorax pustuloglomeratu (Eltink \& Langer, 2014). Anteriorly, the ornament becomes more striped and radial. Lingually the texture is smooth. In labial view, the dentary, the splenial, the postsplenial, the angular, and the surangular can be seen. In lingual view, the surangular, the articular, the angular, the adductor window, the posterior Meckelian fenestra, the prearticular, the postsplenial, the splenial, the coronoid series, and the dentary are preserved, although the sutures between them are not so clear (Figure 4). The adductor window is clearly visible and is formed by the postcoronoid, the angular, the articular, and the prearticular. The posterior Meckelian fenestra is hard to delimit, and the anterior Meckelian fenestra is not well observed because of the fractures but is probably positioned dorsal to the splenial end, ventral to the prearticular. The post-glenoid area (PGA) is very short and it is not possible to see the sutures to classify for certain the type of PGA (Jupp \& Warren, 1986). UFPR 198 PV PGA is shorter than Melosaurids like Mastodonsaurus giganteus, and similar to Rhinesuchids like Rhineceps nyasaensis (Schoch \& Milner, 2000). The PGA of UFPR 0198 PV is formed mainly by the surangular and articular. The symphysis of UFPR 0198 PV has also been inferred, and was probably formed by the dentary and the splenial. The rugose texture of the splenial and the sulcate pattern of the dentary noted by Eltink \& Langer (2014) in A. cosgriffi are not visible. Neither does UFPR 0198 PV display the barlike structure as described in Bageherpeton longignathus by Dias \& Barberena (2001) in lingual view as well as the participation of the coronoids on the symphysis (also seen in Prionosuchus plummeri Price, 1947 and Platyoposaurus stuckenbergi Gubin, 1991). The symphysis of UFPR 0198 PV probably exhibits the same condition as $A$. cosgriffi with a large participation of the dentary (Eltink \& Langer, 2014).

The dentary is the longest bone of the jaw and it is well preserved. On both sides, teeth are present. The dentary bears 19 preserved conical teeth, which get smaller posteriorly. They show the typical temnospondyl pattern, with labyrinthodont infolding in transverse section and longitudinal grooves on the surface. Two tusks are preserved, followed by three small displaced teeth and a bigger tooth. The number of tusks varies a lot in temnospondyls. Eltink \& Langer (2014) described one specimen of Australerpeton cosgriffi with three symphyseal tusks, 76 alveoli, and 48 preserved teeth in the dentary. In labial view, the dentary covers almost the whole jaw, except for the posteriormost part where it contacts the angular and the surangular. The sulcus oralis cannot be seen. It is possible to infer that the dentary contacts the splenial, postsplenial, angular and surangular labially; lingually its ventral limit is made up by the three coronoids and by the splenial. Unfortunately, the sutures and limits are not clearly observable in UFPR 0198 PV, as shown on Figure 4.
The angular is a well-developed bone on the posterior part of the mandible. In labial view, its anterior part ends between the dentary and postsplenial. In lingual view it is possible to observe that the angular contacts the prearticular but the rest of the contacts are not clear. The angular probably contacts the posterior Meckelian fenestra and the postplenial as seen is Australerpeton cosgriffi according to Eltink \& Langer (2014). It is the most ornamented bone in the jaw.

The splenial contacts are not well preserved, since the inferior part, mainly laterally, is not well preserved. Splenial is a wedge-shaped bone narrowing posteriorly to meet the postsplenial and anterior to the anterior coronoid. This condition is the same as in Australerpeton cosgriffi, but the lingual zigzag suture between the splenial and postsplenial identified as an autapomorphy for this species (Eltink \& Langer 2014) was not observed in UFPR 0198 PV.

The postsplenial bone appears on the lingual and labial sides, forming the middle portion of the jaw. It probably contacts posteriorly with the posterior Meckelian fenestra, anteriorly with the splenial and medially with the prearticular. It is not possible to discern the contacts with the angular described for Australerpeton cosgriffi by Eltink \& Langer (2014).

On the lingual surface of the jaw, the prearticular forms a long strip. Ventrally, it contacts the splenial and the postsplenial. Posteriorly it borders the adductor fossa and anteriorly it reaches the middle and anterior coronoid. This bone borders the dorsal part of the adductor fossa, and posteriorly extends a little further than described by Eltink \& Langer (2014) for Australerpeton cosgriffi. This characteristic reduces the participation of the angular on the adductor fossa. In some temnospondyls like Sclerocephalus haeuseri the angular does not even form the adductor fossa (Schoch \& Witzmann, 2009). Anteriorly it probably reaches the middle coronoid.

The sutures between the coronoid series are not visible. The three coronoids do not bear teeth, as observed in many temnospondyls such as in Australerpeton cosgriffi by Eltink \& Langer (2014), Archegosaurus decheni by Witzmann (2006) and Sclerocephalus haeuseri by Schoch \& Witzmann (2009). The elongated posterior coronoid, which is only observed in UFPR 0198 PV in lingual view, forms the dorsal margin of the adductor fossa as in A. cosgriff (Eltink \& Langer, 2014); in the anterior part it probably reaches the middle coronoid. The anterior coronoid probably contacts the dentary and the splenial.

Articular and surangular. The sutures on the post-glenoid area are not visible. The articular and the surangular form the posterior part of the mandible setting up the post-glenoid area. The surangular is ornamented.

\section{DICUSSION}

A recent phylogenetic analysis performed by Eltink et al. (2015) nested Australerpeton cosgriffi within Rhinesuchidae based on: the well-posteroventrally projected tabular horn; the presence of a stapedial groove, a well-developed oblique crest on the pterygoid, a dorsal pterygoid crest formed in the contact 
between the pterygoid and squamosal, a well-marked groove along the posterior border of the interpterygoid vacuity, denticles distributed on the ventral surface of the parasphenoid with an arched posterior margin, and a slit-like post-temporal fenestra. Unfortunately, most of these characteristics, as well as several of the diagnostic features noted by Barberena (1998) related to the palatal view of the skull of $A$. cosgriffi, are not verifiable in the studied specimen. In UFPR 0199 PV the bad preservation of the sutures, and perhaps the superposition of dorsal and ventral surfaces precludes the identification of most of the traits. This could be the reason for the non-observation of the denticles on the parasphenoid, which are well developed in A. cosgriffi.

Eltink et al. (2015) ascribed both the ectopterygoid and the ventral process of the jugal (= insula jugalis) entering the anterior border of the subtemporal fenestra as an autapomorphy of the skull of Australerpeton cosgriffi. In UFPR 0199 PV, in fact, the ectopterygoid forms the subtemporal fenestral margin, and at the left side of the skull is possible to identify this process, but the area is not so clear and the right side is damage.

Eltink et al. (2015) maintained that the long-snouted condition of Australerpeton cosgriffi is unique amongst Rhinesuchidae, and can be recognized by the premaxilla being longer than wide and more than twice the length of the external naris. Additionally, the skull is narrower at the nasal/ frontal contact than half the width at the level of the pineal foramen. The very long-snouted condition, as well as these proportions, is also observed in UFPR $0199 \mathrm{PV}$.

Tooth elements from the marginal dentition of Australerpeton cosgriffi are rounded in cross-section as seen in UFPR 0199 PV, and this trait differs from other rhinesuchids such as Uranocentrodon senekalensis, Rhinesuchus capensis, Rhineceps nyasaensis, Rhinesuchus whaitsi and Rhinesuchus broomianus that have more compressed teeth. The descriptions of Australerpeton cosgriffi by Barberena (1998) and Eltink et al. (2015) show that the posterior premaxillary teeth are larger than the anterior ones (differing from all other known rhinesuchids). In UFPR 0199 PV the teeth, mainly the small premaxillary ones, are not well preserved, precluding comparisons.

Some new unprecedented characteristics described for Australerpeton cosgriffi are revealed in UFPR 0199 PV. Firstly, the huge length of the cultriform process of the parasphenoid, reaching the level of the choanas. Secondly, the pair of longitudinal ridges running parallel on the premaxilla surface, medially to the anterior palatal vacuities. These ridges are similar to what is seen in the vomer of the archegosaurid Archegosaurus decheni (Witzmann, 2006). But contrasting with the condition of Archegosaurus, the ridges of UFPR 0199 $\mathrm{PV}$ are placed on the premaxillae surface without touching the choanae anterior borders in the vomer and lack teeth. These structures have probably never been described for $A$. cosgriffi because UFPR 0199 PV is the biggest and most complete specimen found up to date, and the only one with a complete preservation of the rostrum. Besides UFPR 0199 $\mathrm{PV}$, the only other preserved rostrum is UFRGS-PV-0228-P, which is laterally compressed.
The jaw of UFPR $0198 \mathrm{PV}$ is similar in all aspects to the other Australerpeton cosgriffi specimens. It includes the bone positions and relationships, the ornamentation pattern on the labial face, the disposition and size of the teeth, and the size of the post-glenoid area. The post-glenoid area of UFPR 0198 $\mathrm{PV}$ is the most complete among all A. cosgriffi specimens, mainly because it is not attached to the skull; unfortunately, the presence of the iron oxide cover precludes the visualization of any sutures.

\section{CONCLUSIONS}

The individual represented by specimens UFPR 0198 PV and UFPR 0199 PV shares anatomical characteristics of Australerpeton cosgriffi, including the presence of the ventral process of the jugal, pointed out as an autapomorphy of the latter by Eltink et al. (2015). The comparative description presented in this contribution allows its assignment to this species. The high degree of ossification and its size denote that UFPR 0198 PV and UFPR 0199 PV represent a mature adult individual.

Compared to Australerpeton cosgriffi, the few observed differences, like the absence of denticles on the parasphenoid surface and vomer could be due to preservation artifacts. Notwithstanding, the long cultriform process of the parasphenoid and the long parallel ridges on the premaxilla, are up to date only preserved in this specimen. Therefore, we propose these characters to be added to the diagnosis for A. cosgriffi. UFPR 0198 PV and UFPR 0199 PV comprise the biggest and the most complete $A$. cosgriffi specimen ever found (although the preserved portion of UFPR 0199 PV shows only the ventral side). Possibly these traits could arise late in the ontogeny of this species, and, due to this, only in this specimen are they well developed.

The discovery of UFPR 0198 PV and UFPR 0199 PV at the São Jerônimo da Serra Site corroborates the presence of Australerpeton cosgriffi in this outcrop, which was first reported by Ramos \& Vega (2011), but based only on mandibular fragments. Together with the outcrops along the EFCP railroad and the Monjolo Site (Barberena, 1998; Eltink \& Langer, 2014; Eltink et al., 2015), São Jerônimo da Serra is confirmed as the third site of the Serra do Cadeado region (Morro Pelado Member of Rio do Rasto Formation) recording A. cosgriffi, one of the oldest stereospondyls, that is nested within Rhinesuchidae (Eltink et al., 2015). This provides new evidence that this unique, long-snouted rhinesuchid used to be a common and successful faunal component of the MiddleLate Permian fluvio/lacustrine ecosystems of southern Brazil, reinforcing the idea of a basal stereospondyl diversification outside South Africa.

\section{ACKNOWLEDGEMENTS}

The authors thank CNPq (Conselho Nacional de Desenvolvimento Científico e Tecnológico - Brazil) for financial support. Thanks to R. Cunha for the drawings. 


\section{REFERENCES}

Barberena, M.C. 1998. Australerpeton cosgriffi n. g., n. sp., a Late Permian rhinesuchoid amphibian from Brazil. Anais da Academia Brasileira de Ciências, 70:125-137.

Barberena, M.C. \& Daemon, R.F. 1974. A primeira ocorrência de Amphibia (Labyrinthodontia) na Formação Rio do Rasto, implicações geocronológicas e estratigráficas. In: CONGRESSO BRASILEIRO DE GEOLOGIA, 27, 1974. Anais, Porto Alegre, SBG, p. 251-261.

Barberena, M.C. \& Dias, E.V. 1998. On the presence of a shortsnouted rhinesuchoid amphibian in the Rio do Rasto Formation (Late Permian of Paraná Basin, Brazil). Anais da Academia Brasileira de Ciências, 70:465-468.

Boos, A.D.S.; Kammerer, C.F.; Schultz, C.L. \& Paes Neto, V.D. 2015. A tapinocephalid dinocephalian (Synapsida, Therapsida) from the Rio do Rasto Formation (Paraná Basin, Brazil): taxonomic, ontogenetic and biostratigraphic considerations. Journal of South American Earth Sciences, 63:375-384. doi:10.1016/j.jsames.2015.09.003

Boos, A.D.S.; Kammerer, C.F.; Schultz, C.L.; Soares, M.B. \& Ilha, A.L.R. 2016. A new Dicynodont (Therapsida: Anomodontia) from the Permian of Southern Brazil and its implications for bidentalian origins. PloS ONE, 11:e0155000. doi:10.1371/ journal.pone. 0155000

Boos, A.D.S.; Schultz, C.L.; Vega, C. \& Aumond, J. 2013. On the presence of the Late Permian dicynodont Endothiodon in Brazil and the age of the Rio do Rasto Formation. Palaeontology, 56:837-848. doi:10.1111/pala.12020

Cisneros, J.C.; Abdala, F.; Atayman-Güven, S.; Rubidge, B.S.; Celâl Sxengör, A.M. \& Schultz, C.L. 2012. Carnivorous dinocephalian from the Middle Permian of Brazil and tetrapod dispersal in Pangaea. Proceedings of the National Academy of Sciences of the United States of America, 109:1584-1588. doi:10.1073/ pnas. 1115975109

Cisneros, J.C.; Abdala, F. \& Malabarba, M.C. 2005. Pareiasaurids from the Rio do Rasto Formation, Southern Brazil: biostratigraphic implications for Permian faunas of the Paraná Basin. Revista Brasileira de Paleontologia, 8:13-24.

Cisneros, J.C.; Abdala, F.; Rubidge, B.S.; Dentzien-Dias, P.C. \& Bueno, A.O. 2011. Dental occlusion in a 260-million-year-old therapsid with saber canines from the Permian of Brazil. Science, 331:1603-1605. doi:10.1126/science. 1200305

Dentzien-Dias, P.C.; Figueiredo, A.E.Q.; Horn, B.; Cisneros, J.C. \& Schultz, C.L. 2012. Paleobiology of a unique vertebrate coprolites concentration from Rio do Rasto formation (Middle/ Upper Permian), Paraná Basin, Brazil. Journal of South American Earth Sciences, 40:53-62. doi:10.1016/j.jsames.2012.09.008

Dias, E.V. \& Barberena, M.C. 2001. A temnospondyl amphibian from the Rio do Rasto Formation, Upper Permian of Southern Brazil. Anais da Academia Brasileira de Ciências, 73:136-143.

Dias, E.V. \& Kroeff, T. 2002. The lower jaw of the short-snouted from the Rio do Rasto Formation (Upper Permian), Brazil. In: Boletim Informativo da SBP, Porto Alegre, Sociedade Brasileira de Paleontologia, p. 42 (Paleontologia em Destaque 40).

Dias, E.V. \& Richter, M. 2002. On the squamation of Australerpeton cosgriffi Barberena, a temnospondyl amphibian from the Upper Permian of Brazil. Anais da Academia Brasileira de Ciências, 74:477-490.

Dias, E.V. \& Schultz, C.L. 2003. The first Paleozoic temnospondyl postcranial skeleton from South America. Revista Brasileira de Paleontologia, 6:29-42.
Dias-da-Silva, S. 2012. Middle-Late Permian tetrapods from the Rio do Rasto Formation, Southern Brazil: a biostratigraphic reassessment. Lethaia, 45:109-120. doi:10.1111/j.15023931.2011.00263.x

Eltink, E.; Dias, E.V.; Dias-da-Silva, S.; Schultz, C.L. \& Langer, M.C. 2015. The cranial morphology of the temnospondyl Australerpeton cosgriffi (Tetrapoda: Stereospondyli) from the Middle-Late Permian of Paraná Basin and the phylogenetic relationships of Rhinesuchidae. Zoological Journal of the Linnean Society, 176:835-860. doi:10.1111/zoj.12339

Eltink, E. \& Langer, M.C. 2008. Novos espécimes de temnospôndilos da Serra do Cadeado (nordeste do Paraná). In: SIMPÓSIO BRASILEIRO DE PALEONTOLOGIA DE VERTEBRADOS, 6, 2008. Boletim de Resumos, Ribeirão Preto, SBP, p. 86-88.

Eltink, E. \& Langer, M.C. 2010. Sobre um anfíbio Temnospondyli procedente da Serra do Cadeado, Paraná. In: SIMPÓSIO BRASILEIRO DE PALEONTOLOGIA DE VERTEBRADOS, 7, 2010. Livro de Resumos, Rio de Janeiro, SBP, p. 18.

Eltink, E. \& Langer, M.C. 2011. Cranial anatomy of Australerpeton cosgriffi Barberena 1998: a Permian Temnospondyl from South Brazil. In: CONGRESSO LATINOAMERICANO DE PALEONTOLOGIA DE VERTEBRADOS, 4, 2011. Resumos, San Juan, p. 159.

Eltink, E. \& Langer, M.C. 2014. A new specimen of the Temnospondyl Australerpeton cosgriffi from the late Permian of Brazil (Rio do Rasto formation, Paraná basin): comparative anatomy and phylogenetic. Journal of Vertebrate Paleontology, 34:524-538. doi:10.1080/02724634.2013.826667

Fraas, E. 1889. Die Labyrinthodonten der Schwäbischen Trias. Palaeontographica, 36:1-158.

Goodrich, E.S. 1930. Studies on the structure and development of vertebrates. London, MacMillan, $837 \mathrm{p}$.

Gordon Jr., M. 1947. Classification of the Gondwanic rocks of Paraná, Santa Catarina, and Rio Grande do Sul. Rio de Janeiro, Departamento Nacional da Produção Mineral, Divisão de Geologia e Mineralogia, 20 p. (Notas Preliminares 38).

Gubin, Y.M. 1991. Permian archegosauroid amphibians of the USSR. Trudy Paleontologischeskogo Instituta, 249:1-138. [in Russian].

Gubin, Y.M. 1997. Skull morphology of Archegosaurus decheni Goldfuss (Amphibia, Temnospondyli) from the Early Permian of Germany. Alcheringa, 21:103-121. doi:10.1080/03115519708619178

Haughton, S.H. 1925. Investigations in South African fossil reptiles and Amphibia (Part 13). Annals of the South African Museum, 22:227-261.

Holz, M.; França, A.B.; Souza, P.A.; Iannuzzi, R. \& Rohn, R. 2010. A stratigraphic chart of the Late Carboniferous/Permian succession of the eastern border of the Paraná Basin, Brazil, South America. Journal of South American Earth Sciences, 29:381-399. doi:10.1016/j.jsames.2009.04.004

Jupp, R. \& Warren, A.A. 1986. The mandibles of the Triassic temnospondyl amphibians. Alcheringa, 10:99-124. doi:10.1080/03115518608619164

Langer, M.C. 1998. Are the dinocephalians present in the Brazilian Upper Permian? Journal of African Earth Sciences, 27:129-130.

Langer, M.C.; Eltink, E.; Bittencourt, J.S. \& Rohn, R. 2008. Serra do Cadeado, PR: uma janela paleobiológica para o Permiano continental sul-americano. In: M. Winge; C. Schobbenhaus; C.R.G. Souza; A.C.S. Fernandes; M. Berbert-Born \& E.T. Queiroz (eds.) Sitios Geológicos e Paleontológicos do Brasil, DNPM/CPRM, Comissão Brasileira de Sítios Geológicos e Paleobiológicos (SIGEP), p. 03-19. 
Lee, M.S.Y. 1997. A taxonomic revision of pareiasaurian reptiles: implications for Permian terrestrial palaeoecology. Modern Geology, 21:231-289.

Leonardi, G.; Sedor, A.F. \& Costa, R. 2002. Pegadas de répteis terrestres na Formação Rio do Rasto (Permiano Superior da Bacia do Paraná), Estado do Paraná, Brasil. Arquivos do Museu Nacional, 60:213-216.

Malabarba, M.C.; Abdala, F.; Weiss, F.E. \& Perez, P.A. 2003. New data on the Late Permian vertebrate fauna of Posto Queimado, Rio do Rasto Formation, Southern Brazil. Revista Brasileira de Paleontologia, 6:49-54.

Milner, A.R. 1990. The radiation of temnospondyl amphibians. In: P.D. Taylor \& G.P. Larwood (eds.) Major evolutionary radiations, Clarendon Press, p. 322-349.

Pacheco, C.P.; Eltink, E.; Müller, R.T. \& Dias-Da-Silva, S. 2017. A new Permian temnospondyl with Russian affinities from South America, the new family Konzhukoviidae, and the phylogenetic status of Archegosauroidea. Journal of Systematic Palaeontology, 15:241-256. doi:10.1080/14772019.2016.11 64763

Pauliv, V.E.; Dias, E.V. \& Sedor, F.A. 2012. A new species of Sphenacanthid (Chondrichthyes, Elasmobranchii) from the Rio do Rasto Formation (Paraná Basin), Southern Brazil. Revista Brasileira de Paleontologia, 15:243-250. doi:10.4072/ rbp.2012.3.01

Pauliv, V.E.; Dias, E.V.; Sedor, F.A. \& Ribeiro, A.M. 2014. A new Xenacanthiformes (Chondrichthyes, Elasmobranchii) from the Late Paleozoic Rio do Rasto Formation (Paraná Basin), Southern Brazil. Anais da Academia Brasileira de Ciências, 86:135-145. doi:10.1590/0001-37652014107612

Pawley, K. \& Warren, A. 2006. The appendicular skeleton of Eryops megacephalus (Temnospondyli: Eryopoidea) from the lower Permian of North America. Journal of Paleontology, 80:561580. doi:10.1666/0022-3360(2006)80[561:TASOEM]2.0.CO;2

Ramos, B.D. \& Vega, C.S. 2011. Temnospondyl remains from the late Permian Rio do Rasto Formation (Paraná Basin) of Brazil. Revista Brasileira de Paleontologia, 14:67-74. doi:10.4072/ rbp.2011.1.07

Richter, M. \& Langer, M.C. 1998. Fish remains from the Upper Permian Rio do Rasto Formation (Paraná Basin) of southern Brazil. Journal of African Earth Sciences, 27:158-159.

Schemiko, D.C.B. 2013. A sedimentação do Membro Morro Pelado, Permiamo Superior da Bacia do Paraná: preenchimento de bacia interior por sistemas fluviais distributários. Programa de Pós-Graduação em Geologia Exploratória, Instituto de Geociências, Universidade Federal do Paraná, Dissertação de Mestrado, $90 \mathrm{p}$.

Schoch, R.R. \& Milner, A.R. 2000. Stereospondyli. Stemstereospondyli, Rhinesuchidae, Rhytidostea, Trematosauroidea, Capitosauroidea. In: H.-D. Sues (ed.) Handbuch der Paläoherpetologie, Part 3B, Verlag Friedrich Pfeil, 202 p.

Schoch, R.R \& Witzmann, F. 2009. The temnospondyl Glanochthon from the Permian Meisenheim Formation of Germany. Special Papers in Palaeontology, 81:121-136.

Shishkin, M.A.; Rubidge, B.S. \& Kitching, J.W. 1996. A new lydekkerinid (Amphibia, Temnospondyli) from the lower Triassic of South Africa: implications for evolution of the early capitosauroid cranial pattern. Philosophical Transaction of the Royal Society B, 351:1635-1659. doi:10.1098/rstb.1996.0147

Silva, R.C.; Sedor, F.A. \& Fernandes, A.C.S. 2012. Fossil footprints from the Late Permian of Brazil: an example of hidden biodiversity. Journal of South American Earth Sciences, 38:31-43. doi:10.1016/j.jsames.2012.05.001

Soares, P.C. 1975. Divisão estratigráfica do Mesozóico no estado de São Paulo. Revista Brasileira de Geologia, 5:229-251.

Souza, A.S. 2011. Descrição de materiais de anfibios Temnospondyli registrados na Formação Rio do Rasto (Meso/Neopermiano, Bacia do Paraná), Estado do Paraná. Ciências Biológicas, Universidade Federal do Paraná, Monografia de conclusão de curso, $70 \mathrm{p}$.

Souza, A.S. \& Vega, C.S. 2011. Short-snouted skull, mandible, axial and appendicular skeleton materials of Temnospondyli amphibians (Rio do Rasto Formation, Paraná Basin, Brazil). In: CONGRESSO LATINOAMERICANO DE PALEONTOLOGIA DE VERTEBRADOS, 4, 2011. Resumos, San Juan, p. 67.

Steyer, J.S.; Damiani, R.; Sidor, C.A.; O'Keefe, R.; Larsson, H.C.E.; Maga, A. \& Ide, O. 2006. The vertebrate fauna of the Upper Permian of Niger. IV. Nigerpeton ricqlesi (Temnospondyli: Cochleosauridae), and the edopoid colonization of Gondwana. Journal of Vertebrate Paleontology, 26:18-28. doi: 10.1671/0272-4634(2006)26[18:TVFOTU]2.0.CO;2

Strapasson, A.; Pinheiro, F.L. \& Soares, M.B. 2015. On a new stereospondylomorph temnospondyl from the Middle/Late Permian of Southern Brazil. Acta Palaeontologica Polonica, 60:843-855. doi:10.4202/app.00059.2014

Watson, D.M.S. 1919. The structure, evolution and origin of the Amphibia. The 'Orders' Rachitomi and Stereospondyli. Philosophical Transaction of the Royal Society B, 209:1-73. doi:10.1098/rstb.1920.0001

Watson, D.M.S. 1962. The evolution of Labyrinthodonts Philosophical Transactions of Royal Society B, 245:219-265. doi:10.1098/rstb.1962.0010

Wernerburg, R. \& Schneider, J. 1996. The Permian temnospondyl amphibians of India. Special Papers in Paleontology, 52:105128.

Witzmann, F. 2006. Cranial morphology and ontogeny of the Permo-Carboniferous temnospondyl Archegosaurus decheni Goldfuss, 1847 from the Saar-Nahe Basin, Germany. Earth and Environmental Science Transactions of The Royal Society of Edinburgh, 96:131-162. doi: 10.1017/S0263593300001279

Yates, A.M. 1999. The Lapillopsidae: a new family of small temnospondyls from the Early Triassic of Australia. Journal of Vertebrate Paleontology, 19:302-320. doi:10.1080/02724634. 1999.10011143

Yates, A.M. \& Warren, A.A. 2000. The phylogeny of the 'higher' temnospondyls (Vertebrata: Choanata) and its implications for the monophyly and origins of the Stereospondyli. Zoological Journal of the Linnean Society, 128:77-121. doi:10.1006/ zjls.1998.0184

Zittel, K.A. 1887-1890. Handbuch der Paläeontologie. Abteilung 1. Palaozoologie Band III: Vertebrata (Pisces, Amphibia, Reptilia, Aves). Berlin, Oldenbourg, 890 p.

Received in February, 2017; accepted in September, 2017. 